\title{
Protein kinase C-mediated cell death mode switch induced by high glucose
}

\author{
R Fujita ${ }^{1}$ and $\mathrm{H} \mathrm{Ueda}^{*}, 1$ \\ 1 Division of Molecular Pharmacology and Neuroscience, Nagasaki University \\ Graduate School of Biomedical Sciences, Nagasaki, Japan \\ * Correspondence: H Ueda, Division of Molecular Pharmacology and \\ Neuroscience, Nagasaki University Graduate School of Biomedical Sciences, \\ 1-14 Bunkyo-machi, Nagasaki 852-8521, Japan. Tel: + 81-95-819-2421; \\ Fax: + 81-95-819-2420; E-mail: ueda@net.nagasaki-u.ac.jp
}

Received 07.3.03; revised 19.5.03; accepted 20.6.03; published online 22 August 2003

Edited by $\mathrm{H}$ Ichijo

\begin{abstract}
Cortical neurons rapidly die in necrosis due to poor glucose uptake in the low-density (LD) culture under serum-free condition without any supplements. The scanning and transmission electron microscopical analyses characterized the necrosis by membrane disruption, mitochondrial swelling and loss of cytoplasmic electron density. High-glucose treatment delayed the neuronal death by suppressing necrosis, but induced apoptosis through increase in Bax levels, cytochrome $c$ release, caspase-3 activation and DNA ladder formation. Although pyruvate as well as high glucose inhibited necrotic cell death and rapid decrease in cellular ATP levels, possibly related to decreased $\left[{ }^{3} \mathrm{H}\right]-2$-deoxy glucose uptake under the serum-free condition, it did not induce apoptosis. Protein kinase $\mathbf{C}$ inhibitors blocked these changes related to the cell death mode switch. Several neurotrophic factors did not affect the necrosis, but potentiated high-glucose-induced survival activity, while inhibiting cytochrome $c$ release. All these results suggest that high-glucose treatment causes neuronal cell death mode switch by inhibiting necrosis, while inducing apoptosis, which is prevented by neurotrophic factors.

Cell Death and Differentiation (2003) 10, 1336-1347, doi:10.1038/ sj.cdd. 4401300

Published online 22 August 2003
\end{abstract}

Keywords: necrosis; apoptosis; glucose; protein kinase C; ATP

Abbreviations: MCAO, middle cerebral artery occlusion; GFAP, glial fibrilary acidic protein; LD, low-density; MAP-2, microtubule-associated protein-2; TUNEL, terminal deoxyribonucleotidyl transferase-mediated dUTP-biotim mick endlabeling; GLUT, glucose transporter

\section{Introduction}

Traumatic brain injury causes cell death through direct mechanical damage, as well as through delayed injury induced by endogenous, autodestructive processes. ${ }^{1}$
Such death may occur through either necrosis or apoptosis. $^{2,3}$ Ischemia and/or metabolic impairment accompany traumatic central nervous system injury in animals ${ }^{4,5}$ and in humans. ${ }^{6,7}$ The ischemic area induced by middle cerebral artery occlusion (MCAO) can be divided into an ischemic core and the penumbra area. In the core, there is a rapid necrotic cell death, whereas in the penumbra apoptosis occurs more slowly. ${ }^{8-10}$ Since necrotic cells induce secondary damages due to the damage of surrounding cells, while apoptotic cells do not, ${ }^{11,12}$ a switch in the mode of cell death from necrosis to apoptosis could play a role in ameliorating the spread of a cell death in the brain.

Necrosis is characterized by loss of membrane integrity, disruption of intracellular organelles, cellular swelling and lysis, while apoptosis involves reduction of intracellular volume, nuclear condensation and fragmentation. ${ }^{13,14}$ Although the molecular mechanisms underlying apoptosis execution are now well characterized, ${ }^{15}$ little is known about the mechanisms underlying necrosis. In previous studies, we observed that cortical neurons die by necrosis in low-density and serum-free culture, and the mode of cell death changes to apoptosis as cell density increases. ${ }^{16,17}$ Most recently, we found that some neuronal conditioned medium factors switch the cell death mode from necrosis to apoptosis. ${ }^{17}$ This switch in the mode of cell death is correlated with cellular ATP levels, as it is altered by various reagents such as oligomycin (mitochondrial $F_{0}-F_{1}$ ATPase inhibitor), caspase inhibitor or poly (ADP-ribose) polymerase (PARP) inhibitor. These findings are closely related to observations that oligomycin switches the apoptosis induced by Fas or oxidative stress to necrosis. ${ }^{18,19}$ Since high energy levels are required for the execution of apoptosis but not for necrosis, ${ }^{20,21}$ ATP may have a key role in regulating the mode of cell death. ${ }^{22,23}$ However, it remains to be seen whether the increase in cellular ATP levels might switch the necrotic cell death to apoptotic one.

Alteration of glucose disposition might also be related to the cell death mode switch, since the level of glucose uptake is low in the necrotic ischemic core, while it is high in the surrounding penumbra area. ${ }^{9}$ In the present study, we attempted to see whether such cell death mode switch is affected by raising cellular ATP levels by adding high glucose.

\section{Results}

Increase in cellular ATP levels and survival activity by high-glucose treatment

When cortical cells of embryonic (E17) rats were seeded at $1 \times 10^{5} \mathrm{cells} / \mathrm{cm}^{2}$ (low-density; LD) and cultured with or without serum, most of the cells attached to the plate within $1 \mathrm{~h}$. The population of microtubule-associated protein-2 (MAP-2, a neuron marker)-positive cells was $95 \%$, while those of glial fibrillary acidic protein (GFAP, an astrocyte 

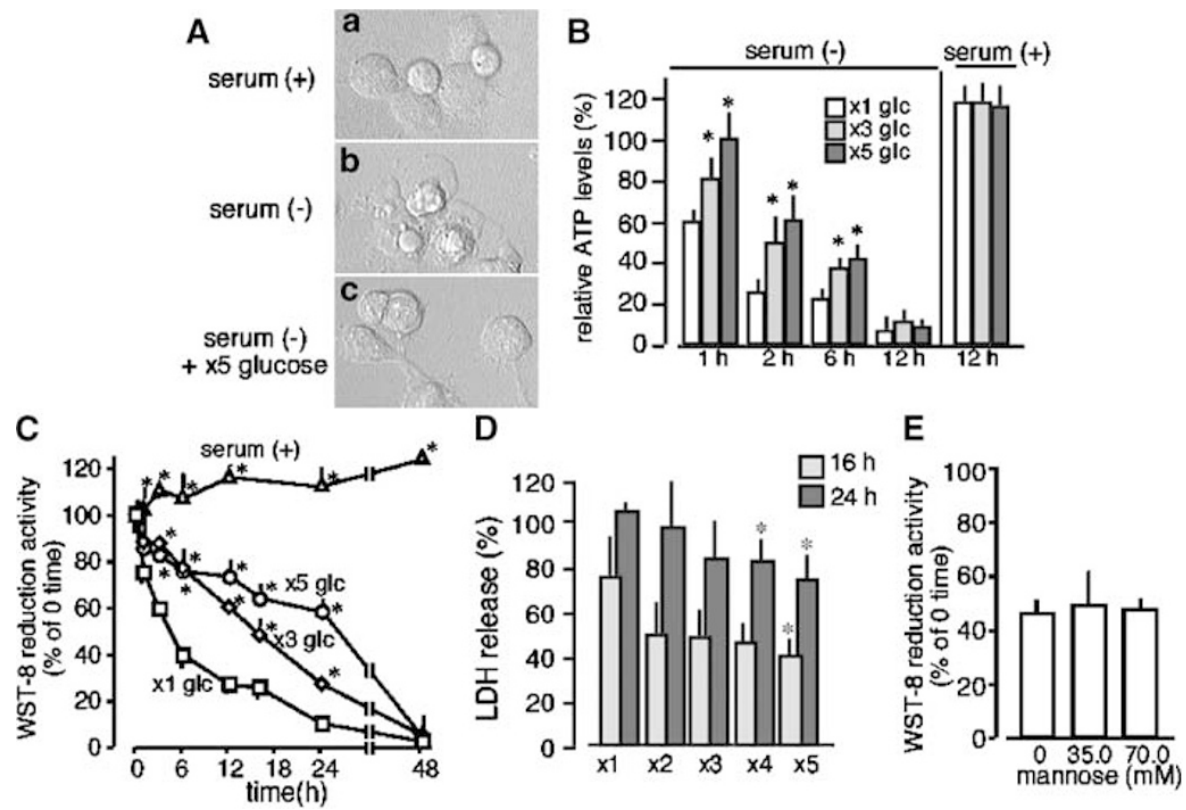

Figure 1 Increase in survival activity and cellular ATP levels by high-glucose treatment. (A) Phase-contrast photographs of neurons in the serum-plus (a), serum-free (b) and serum-free $+\times 5$ high-glucose cultures (c). (B) Time course of changes in cellular ATP levels in the culture containing different glucose concentrations. Relative ATP levels were calculated as the percent of time 0 level. (C, D) Concentration dependence and time course of change in glucose-treated culture, measured by WST-8 reduction activity (C) and LDH release (D). (E) Lack of mannose-induced survival measured by WST-8 reduction activity. Results were represented as percentage of 0 time activity. All data are the means + S.E.M. from three independent experiments. ${ }^{*} P<0.05$, compared to $\times 1$ glucose culture

marker) and OX-42 (a microglia marker)-positive cells were 3.4 and $0.8 \%$, respectively (data not shown), indicating that the cells were mostly neurons. In the presence of serum, most neurons looked healthy and had neurites by $12 \mathrm{~h}$ (Figure 1Aa). In contrast, serum-free neurons exhibited dilated cell volume, and had no neurites (Figure $1 \mathrm{Ab})$. Our previous study revealed that the neurons in this serum-free culture are clearly characterized to die by necrosis. ${ }^{17}$ In $\times 5$ glucose $(87.5 \mathrm{mM})$ and serum-free medium, on the other hand, most neurons appeared healthy and had neurites (Figure 1Ac).

The cellular ATP level of cortical neurons was rapidly decreased in the LD and serum-free culture, while there was no decrease in the ATP level in the presence of serum (Figure 1B). When cortical neurons were grown in the presence of various concentrations $(1 \times, 3 \times$ and $5 \times ; 17.5$, 52.5 and $87.5 \mathrm{mM}$ ) of glucose, a concentration-dependent increase in cellular ATP levels was observed by $6 \mathrm{~h}$ (Figure 1B). Survival activity measured with WST-8 reduction activity due to mitochondrial activity was also rapidly decreased in the LD and serum-free culture, while no change was seen in the presence of serum (Figure 1C). The addition of high-glucose concentration-dependently increased the survival activity. Similar neuroprotection by high-glucose treatments was also observed in the decrease in $\mathrm{LDH}$ release due to loss of membrane integrity (Figure 1D). However, addition of $70 \mathrm{mM}$ mannose to normal-glucose culture did not affect the survival activity in the WST-8 reduction assay (Figure 1E), suggesting that the neuroprotection by high-glucose treatment is unlikely due to the high osmolarity. Thus, this mechanism through a delay of decrease in ATP levels may be involved in the necrosis inhibition.

\section{Scanning electron microscopy analysis of cortical neuron cultured under the serum-free and high-glucose condition}

Scanning electron microscopy (SEM) indicated that the cortical neuron in the presence of serum showed lamellipodium at the time point of $6 \mathrm{~h}$ after the start of culture (Figure 2Aa). On the other hand, neuron in the serum-free culture showed marked membrane disruption on the lamellipodium at $6 \mathrm{~h}$; then the total cell structure except for nuclei was disintegrated at $12 \mathrm{~h}$ (Figure 2Bb). Addition of high glucose completely protected the neuron from membrane disruption, but induced membrane smoothing, bubbling and cell fragmentation (Figure 2Ca,b).

\section{TEM analysis of high-glucose-induced cell death mode switch in the serum-free culture}

On the other hand, transmission electron microscopy (TEM) indicated that cellular organelles appeared healthy in the neurons grown with serum. Neither damages in membrane and nucleus (Figure $3 \mathrm{Aa}$ ) nor mitochondrial swelling (Figure $3 A b)$ was observed. However, neurons grown without serum had disrupted plasma membranes without damage in nucleus (Figure 3Ba) and swollen mitochondria (Figure 3Bb). The $\times 5$ glucose treatment alleviated these membranes and mitochondrial damages occurred in serum-free culture, but caused nuclear fragmentation (Figure $3 \mathrm{Ca}, \mathrm{b}$ ).

\section{Characterization of cell death mode switch induced by high-glucose treatment}

Fluorescein isothiocyanate (FITC)-conjugated annexin $\mathrm{V}$ has been utilized to detect the externalization of phosphatidylserine 

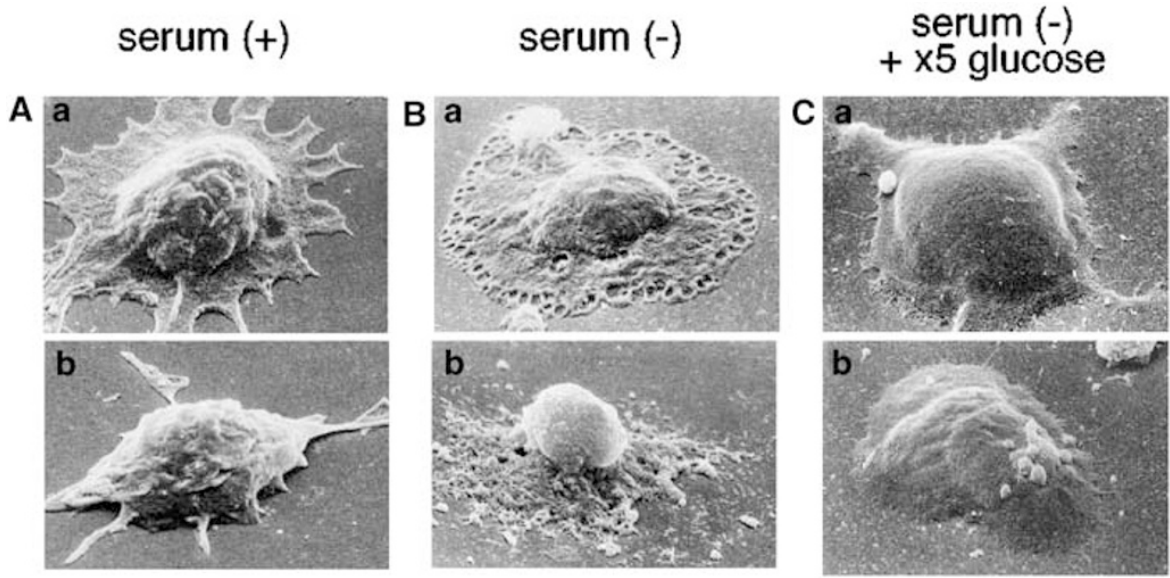

Figure 2 SEM analysis of high-glucose-induced cell death mode switch in the serum-free culture: representative SEM pictures. The samples are the neurons $6 \mathrm{~h}$ (Aa, $\mathrm{Ba}$ and $\mathrm{Ca}$ ) and $12 \mathrm{~h}(\mathbf{A b}, \mathbf{B b}$ and $\mathbf{C b})$ after the start of culture in the serum-plus $(\mathbf{A})$, serum-free $(\mathbf{B})$ and serum-free $+\times 5$ high-glucose cultures $(\mathbf{C})$, respectively
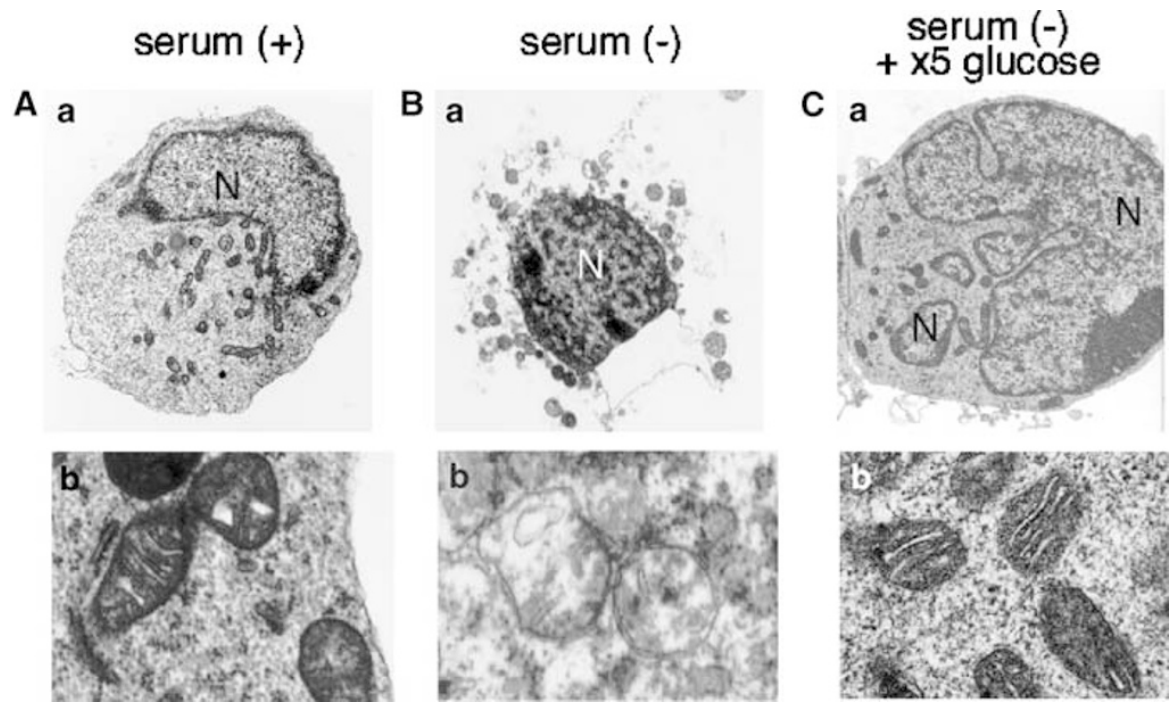

Figure 3 TEM analysis of high-glucose-induced cell death mode switch in the serum-free culture. Neurons $12 \mathrm{~h}$ after start of serum-plus (A), serum-free (B) and serumfree $+\times 5$ high-glucose $(\mathbf{C})$ cultures were used for TEM observation. Low magnification and high magnification of mitochondria in the serum-plus (Aa, b), serum-free (Ba, b) and serum-free $+\times 5$ high-glucose $(\mathbf{C a}, \mathrm{b})$ cultures, respectively. N: nuclei

that occurs at an early stage of apoptosis. ${ }^{24}$ Propidium iodide $(\mathrm{PI})$ is used for a necrosis marker due to the cell membrane destruction. Very few annexin V-positive cells $(12.9 \%$ of total cells) were observed $3 \mathrm{~h}$ after the start of the LD culture containing normal, $\times 1$ glucose $(17.5 \mathrm{mM})$, in which $\mathrm{PI}$ positive cells were predominant $(68.6 \%$, see Figure $4 A a, b)$. The apoptosis/necrosis ratio (annexin V-positive cells/PIpositive cells) was calculated to be 0.19 . Following the $\times 3$ and $\times 5$ high-glucose treatment, the population of PI-stained cells was markedly reduced, while most cells became annexin $\mathrm{V}$-positive (Figure $4 \mathrm{Ab}, \mathrm{C}$ and $\mathrm{B}$ ). The ratio was markedly increased to 60.2 and 46.2 by $\times 3$ and $\times 5$ glucose, respectively.

The conversion of procaspase- 3 to active caspase- 3 is generally accepted to be the most reliable indicator of apoptosis. ${ }^{25}$ As shown in Figures $4 \mathrm{Ca}$ and $\mathrm{D}$, most cells were PI-positive and active caspase-3-negative in $\times 1$ glucose $12 \mathrm{~h}$ after the start of culture. The apoptosis/necrosis ratio (active caspase-3-positive cells/PI-positive cells) was calculated to be 0.06 in normal-glucose culture. Similar high-glucoseinduced cell death mode switch to apoptosis was also observed in this paradigm of experiments (Figures 4Cb,c). The apoptosis ratio was markedly increased to 2.50 and 5.45 by $\times 3$ and $\times 5$ glucose (Figure 4D), respectively. When cell lysates were used for the measurement of caspase-3-like activity, high-glucose treatments significantly increased the activity in a concentration-dependent manner (Figure 4G).

Caspase-3 activation is followed by DNA fragmentation, which is manifested by TUNEL activity and DNA ladder formation. As shown in Figure 4Ea and F, TUNEL activity was not observed under the normal-glucose condition, while it was marked by the addition of high glucose (Figure 4Eb,c, F) at $24 \mathrm{~h}$ after the start of culture. Figure $4 \mathrm{H}$ showed typical DNA ladder formation only in the high-glucose culture. 
A

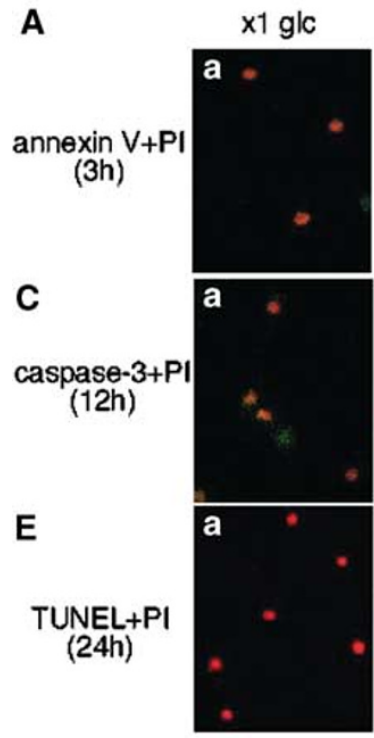

G

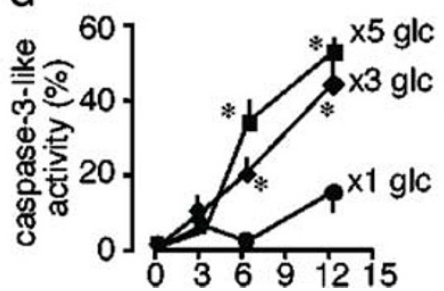

$\times 3 \mathrm{glc}$
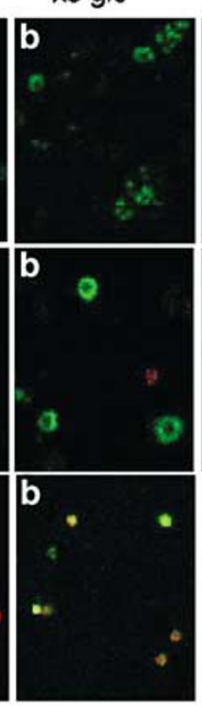
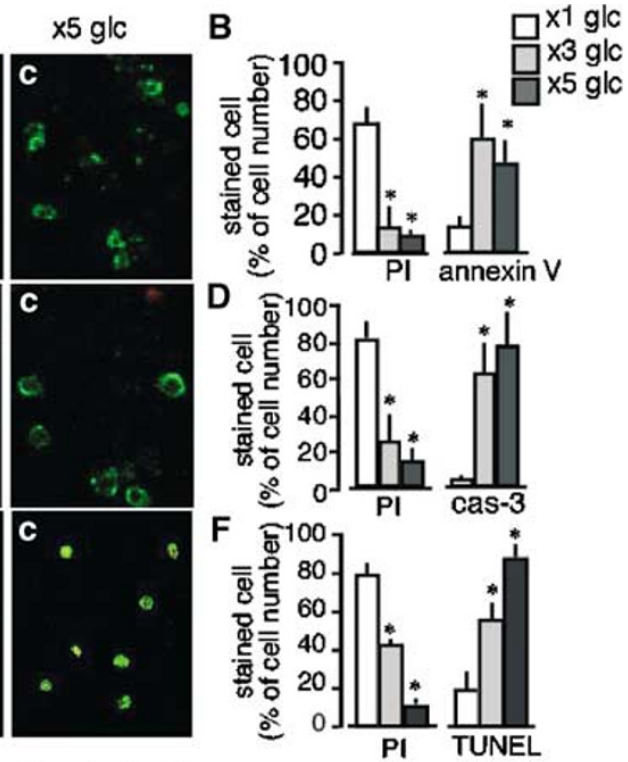

H $\quad M \quad 1 \quad 2 \quad 3$

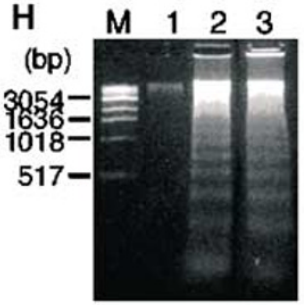

Figure 4 Characterization of cell death mode switch induced by high-glucose treatment. (A-F) Representative photographs of double staining of PI (red) and annexin V (FITC labeling: green) (Aa-C), PI (red) and active caspase-3 (FITC labeling: green) (Ca-C) or PI (red) and TUNEL (FITC labeling: green) (Ea-C) in the presence of different concentrations of glucose (glc). (B, D and F) Quantitative comparisons of specifically stained cell population for PI/annexin V (B), for PI/caspase-3 (D) and PI/ TUNEL (F). (G) High-glucose-induced increase in caspase-3-like protease activity. (H) Ladder formation of NA derived from neurons harvested from serum-free and high-glucose cultures. Lane M: standard DNA markers; lane 1: normal $\times 1$ glucose; lane 2: $\times 3$ glucose; lane 3: $\times 5$ glucose, respectively. Data (B, D, F and G) are the means + S.E.M. from three independent experiments. ${ }^{*} P<0.05$, compared to $1 \times$ glucose culture

\section{High-glucose-caused induction of cellular proapoptotic mechanisms}

To characterize the apoptosis mechanisms by high-glucose treatment, Western blot analyses for $\mathrm{Bcl}-2$ family proteins and caspase molecules were carried out. As shown in Figure 5A, proapoptotic Bax expression was increased linearly till $12 \mathrm{~h}$ after the start of high-glucose culture. At the time point of $12 \mathrm{~h}$, a slight increase in the level of Bim, another proapoptotic protein was observed, while there was no or slight decrease in $\mathrm{Bcl}-2$ or Bcl-xL, respectively (Figure $5 \mathrm{~B}$ ).

Cytochrome $C$ is a key molecule in the activation of caspase- 9 and caspase- 3 , and its release from mitochondria is regulated by the actions of $\mathrm{Bcl}-2$ family proteins, such as proapoptotic Bax and antiapoptotic Bcl-2. ${ }^{26-28}$ As shown in Figure $5 \mathrm{Ca}-\mathrm{c}$, neurons were double-labeled with cytochrome $c$ and Mitotracker Red CMXRos, a fluorescent probe for mitochondria at $12 \mathrm{~h}$ in normal-glucose and serum-free medium. In the high-glucose culture, however, this double labeling disappeared by $12 \mathrm{~h}$ (Figure $5 \mathrm{Cd}-\mathrm{f}$ ). These findings suggest that the serum-free stress itself did not cause cytochrome $c$ release from mitochondria or proapoptotic mechanism, while the high-glucose treatment did.

Bax-mitochondrial pathway drives both caspase-9 and caspase-3 activation through mitochondrial cytochrome $c$ release,${ }^{29}$ while Fas/TNF receptor and endoplasmic reticulum (ER)-stress pathways drive caspase-8 and caspase-12, respectively. ${ }^{30,31}$ The high-glucose treatment markedly increased active caspase- 9 and caspase-3 levels (Figure 5D). However, the treatment did not affect the caspase-12 levels, while significant caspase-8 levels were not detected from both normal and high-glucose preparations at $12 \mathrm{~h}$ (data not shown).

\section{Recovery of reduced $\left[{ }^{3} \mathrm{H}\right]$-2-deoxy glucose uptake by high-glucose treatment}

When the incorporated glucose level was evaluated by $\left[{ }^{3} \mathrm{H}\right]-2-$ deoxy glucose $\left(\left[{ }^{3} \mathrm{H}\right]-2-D G\right)$ uptake, the level was found to markedly decrease in the serum-free culture, compared to that in the presence of serum (Figure 6a). The translocated GLUT1 and GLUT4 into plasma membrane disappeared in the serum-free culture (Figure $6 b$ ), suggesting that this change may cause the reduction of $\left.{ }^{3} \mathrm{H}\right]-2-\mathrm{DG}$ uptake in the serum-free culture. On the other hand, in the serum-free and high-glucose $(\times 3$ or $\times 5)$ culture, $\left[{ }^{3} \mathrm{H}\right]-2-\mathrm{DG}$ uptake corrected by high-glucose dilution was increased just to the level in the presence of normal glucose and serum (Figure 6a). However, high-glucose treatment did not induce the localization of 
A
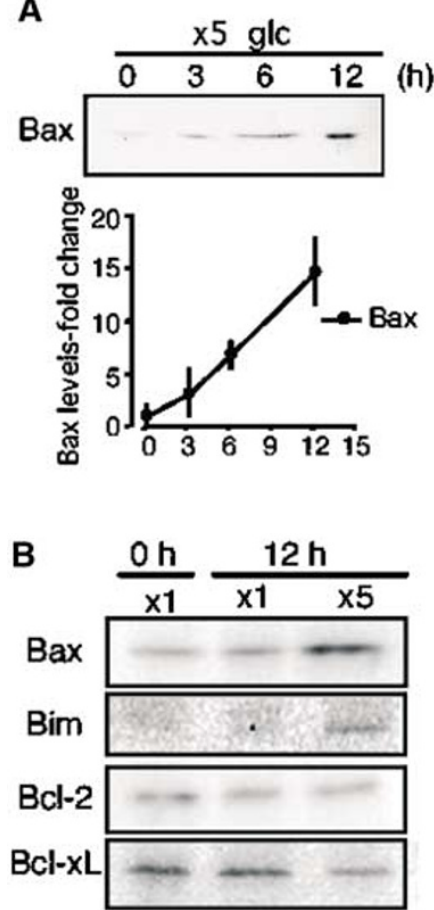

C

serum (-)

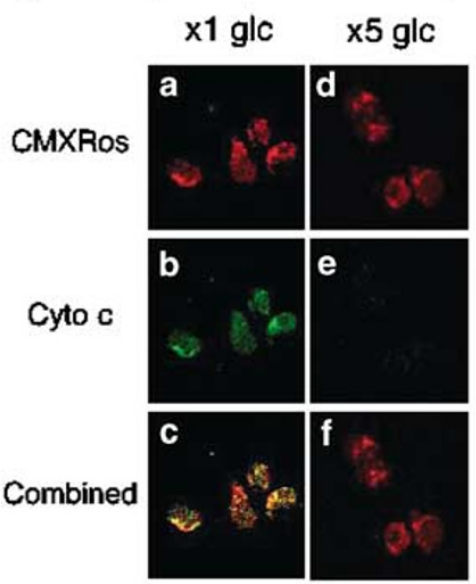

D

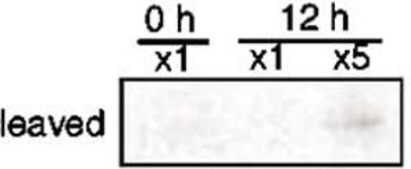

caspase 3

\section{procaspase 9}

cleaved

\section{caspase 9}

Figure 5 High-glucose-caused induction of cellular proapoptotic mechanisms. (A) Time course of Bax expression by immunoblot analyses. The results show representative photographs of immunoreactivities of Bax at various time points of high-glucose culture (upper) and quantitative comparison of the increases of immunoreactive Bax activities (bottom). Immunoreactivity was quantitated by using NIH image for Macintosh. Data are the means + S.E.M. from three independent experiments. (B) Differential change of expression of Bcl-2 family proteins by high-glucose culture $12 \mathrm{~h}$ after the start of culture. (C) CMXRos (red; mitochondrial membrane potential $\Delta \Psi_{m}$ ) and cytochrome $c$ (FITC labeling: green; cyto $c$ ) staining were observed in cortical neurons treated with serum-free $\times 1$ glucose (a-c), serumfree $\times 5$ glucose $(\mathrm{d}-\mathrm{f})$ after incubation for $12 \mathrm{~h}$. (D) Immunoblot analyses of protein expression of caspase- 3 and caspase-9 proteins after incubation for $12 \mathrm{~h}$

GLUT1 and GLUT4 into plasma membrane (Figure 6b). Thus, the high-glucose-induced apoptosis induction is unlikely, due to enhanced glucose incorporation.

\section{Pyruvate prevents the necrosis through raising cellular ATP levels, but does not induce apoptosis}

The addition of $10 \mathrm{mM}$ pyruvate to the serum-free culture markedly delayed the decline of WST-8 survival activity (Figure $7 a$ ). Approximately $80 \%$ of survival activity retained at the time point of $24 \mathrm{~h}$ after the serum-free culture, and its activity was more potent than the high-glucose $(\times 5)$ mediated one (58.3\%). Concentration dependency also supports the view that pyruvate has higher potency in retaining the survival activity than glucose (Figure $7 \mathrm{~b}$ ). As shown in Figure 7c, the rate of decrease in ATP levels was slower with pyruvate than that with high glucose. Approximately $50 \%$ of initial ATP levels were retained in neurons treated with pyruvate at $12 \mathrm{~h}$ after the start of serum-free culture, while less than $10 \%$ levels were with high glucose. However, the pyruvate treatment completely prevented necrosis manifested with $\mathrm{PI}$ staining, but did not induce apoptosis with annexin $\mathrm{V}$ staining (Figure 7d).

\section{High-glucose-induced survival activity through phospholipase $\mathbf{C}$ and protein kinase $\mathbf{C}$ activation}

We attempted to examine the effects of inhibitors for various protein kinases on the neuronal survival activity in the high- glucose culture, to get some clues for the cellular signaling of high-glucose-induced cell death mode switch. Here we used various representative inhibitors such as herbimycin $\mathrm{A}(3 \mu \mathrm{M})$ for tyrosine kinase, calphostin $\mathrm{C}(3 \mu \mathrm{M})$ and GF109203X $(0.1 \mu \mathrm{M})$ for protein kinase $\mathrm{C}(\mathrm{PKC})$, wortmannin $(1 \mu \mathrm{M})$ for phosphatidylinositol-3 kinase (PI-3 kinase), U0126 $(1 \mu \mathrm{M})$ for mitogen-activated protein kinase kinase (MEK), SP600125 $(1 \mu \mathrm{M})$ for c-Jun N-terminal kinase (JNK), SB203580 $(1 \mu \mathrm{M})$ for p38 mitogen-activated protein kinase (p38MAPK), KT5720 $(1 \mu \mathrm{M})$ for cyclic AMP-dependent protein kinase (PKA) and KN93 $(1 \mu \mathrm{M})$ for $\mathrm{Ca}^{2+} /$ calmodulin kinase II. These compounds alone did not affect survival activity under the normalglucose and serum-free culture (data not shown). Among nine compounds, only PKC inhibitors (calphostin $\mathrm{C}$ and GF109203X) significantly attenuated it (Figure 8A). Thapsigargin $(1 \mu \mathrm{M})$, an intracellular $\mathrm{Ca}^{2+}$ store depletor, and U73122 (1 $\mu \mathrm{M})$, a phospholipase $\mathrm{C}$ inhibitor, but not U73343 $(1 \mu \mathrm{M})$, its inactive isomer, blocked the high-glucose-induced survival activity. Furthermore, high-glucose treatment significantly increased the PKC activity in a calphostin C- and U73122-reversible manner (Figure 8B). All these findings suggest that the high-glucose-induced survival activity is mediated through phospholipase $\mathrm{C}$ and PKC mechanisms.

\section{Protein kinase C-mediated cell death mode switch induced by high glucose}

In the experiment using double staining with Hoechst 33342 and PI staining, neurons in the normal-glucose and 


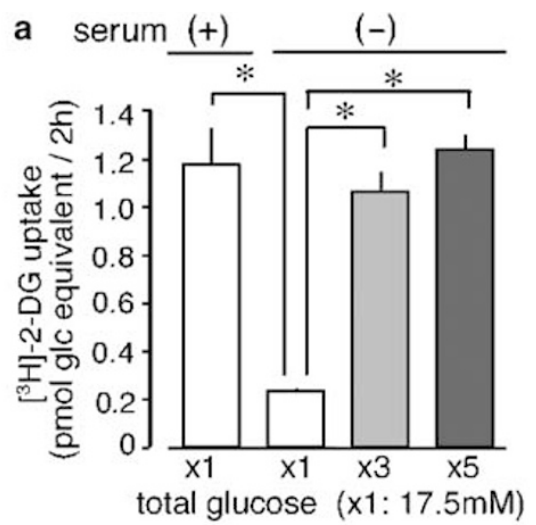

b

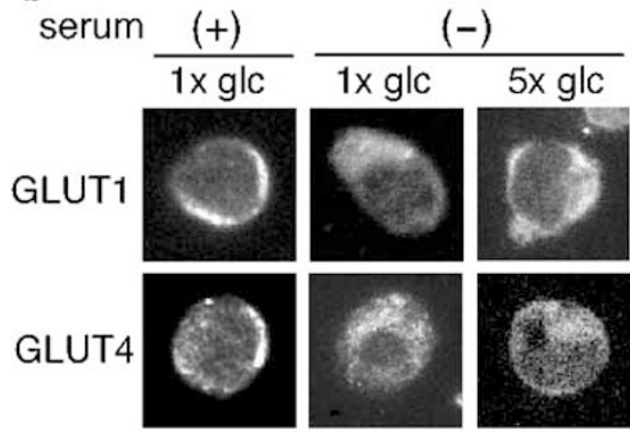

Figure 6 Recovery of reduced $\left[{ }^{3} \mathrm{H}\right]-2$-deoxy glucose $\left(\left[{ }^{3} \mathrm{H}\right]-2-\mathrm{DG}\right)$ uptake by high-glucose treatment in the serum-free culture. (A) $\left.{ }^{3} \mathrm{H}\right]-2-\mathrm{DG}$ uptake. Cellula glucose incorporation was evaluated by the $\left[{ }^{3} \mathrm{H}\right]-2-\mathrm{DG}$ uptake for $2 \mathrm{~h}$ from the start of $\times 1$ glucose $(17.5 \mathrm{mM})$ containing serum-plus culture, or $\times 1, \times 3$ and $\times 5$ glucose $(17.5,52.5$ and $87.5 \mathrm{mM})$ containing serum-free culture. Results represent pmol glucose equivalent per $2 \mathrm{~h}$, regarding a tracer $\left[{ }^{3} \mathrm{H}\right]-2-\mathrm{DG}$ as glucose. (B) GLUT1 or GLUT4 staining in the presence or absence of serum condition, and normal $(1 \times \mathrm{glc})$ and high-glucose $(5 \times \mathrm{glc})$ treatment. Results are representative photographs of immunocytochemistry $2 \mathrm{~h}$ after the start of culture

serum-free culture were intensely stained by $\mathrm{PI}$, but not by Hoechst 33342 (Figure 8Ca,b). In the high-glucose culture, however, most of the neurons showed marked nuclear condensation or fragmentation stained by Hoechst 33342 , but no PI-positive neuron was observed (Figure 8Cc,d). Such typical cell death mode switch was clearly reversed by calphostin C (Figure 8Ce,f) and GF109203X (data not shown). Calphostin $C$ reversal of high-glucose-induced cell death mode switch was also observed when colabeling with annexin $\mathrm{V}$ and $\mathrm{PI}$ was carried out (Figure $8 \mathrm{Cg}-\mathrm{i}$ ). Furthermore, the proapoptotic cytochrome $c$ release and enhanced Bax expression induced by high glucose were also blocked by calphostin C (Figure 8D, E).

\section{Potentiation of high-glucose-induced survival activity and blockade of high-glucose-induced cytochrome $c$ release by neurotrophic factors}

The addition of nerve growth factor (NGF, $100 \mathrm{ng} / \mathrm{ml}$ ), brainderived neurotrophic factor (BDNF, $100 \mathrm{ng} / \mathrm{ml}$ ) or basic fibroblast growth factor (bFGF, $100 \mathrm{ng} / \mathrm{ml}$ ) did not affect the survival activity $12 \mathrm{~h}$ after the start of serum-free culture, measured with WST-8 assay (Figure 9A). However, these
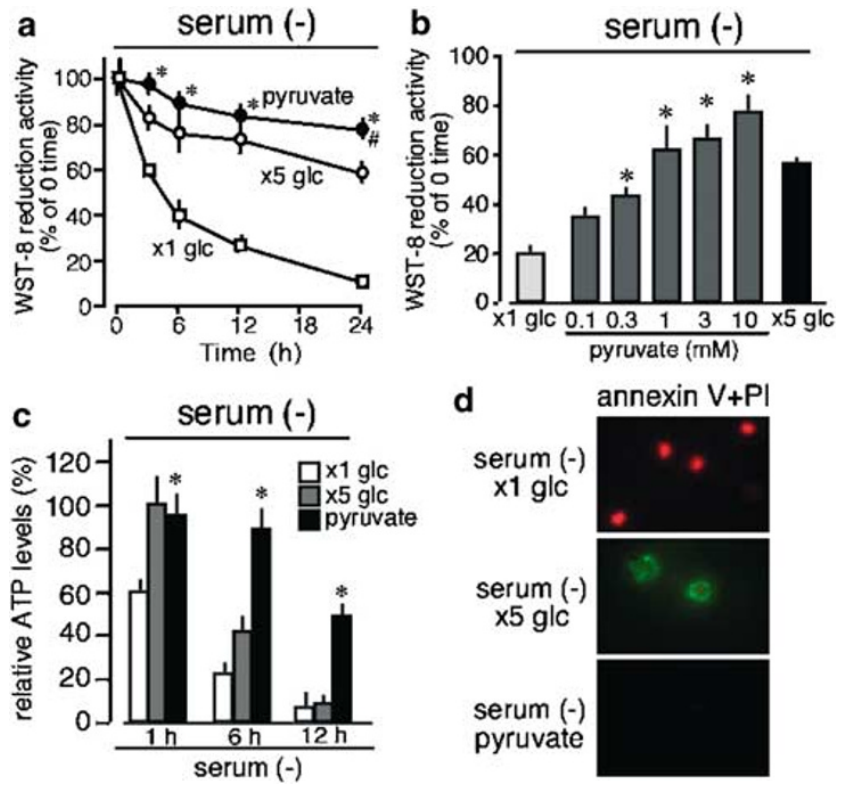

Figure 7 Pyruvate prevents the necrosis through raising cellular ATP levels, but dose not induce apoptosis. Time course (A) and concentration dependency (B) of pyruvate $(10 \mathrm{mM})$-induced changes in WST-8 reduction activity. (C) Time course of pyruvate $(10 \mathrm{mM})$-induced changes in cellular ATP levels. Relative ATP levels were calculated as the percent of the time 0 level. (D) Double staining of $\mathrm{PI}$ (red) and annexin V (FITC labeling: green) of neurons in the serum-free culture added with normal-glucose $(\times 1 \mathrm{glc})$, high glucose $(\times 5 \mathrm{glc})$ and pyruvate $(10 \mathrm{mM})$. Data $(\mathbf{A}-\mathbf{C})$ are the means + S.E.M. from three independent experiments. ${ }^{*} P<0.05$, compared to $\times 1$ glucose vehicle, ${ }^{\sharp} P<0.05$, compared to $\times 5$ glucose vehicle

neurotrophic factors all significantly potentiated the highglucose-induced survival activity. Further addition of herbimycin $\mathrm{A}(3 \mu \mathrm{M})$ or $\mathrm{K} 252 \mathrm{a}(1 \mu \mathrm{M}$, a TrkB inhibitor) blocked the BDNF-induced potentiation, while inhibitors alone did not affect the basal survival activity (data not shown).

On the other hand, BDNF treatment inhibited the highglucose-induced cytochrome $c$ release from mitochondria (Figure $9 \mathrm{Ba}-\mathrm{C}$ ), in a herbimycin $\mathrm{A}$ - or K252a-reversible manner (Figure 9Bd-i). However, the inhibitors alone did not affect the high-glucose-induced cytochrome $c$ release (Figure9j-o). All these findings suggest that high-glucose treatment converted the serum-free stress-induced necrosis to apoptosis, which will be blocked by some tyrosine kinases activated by neurotrophic factors.

\section{Discussion}

Neuronal death observed under serum-free conditions without any supplements has unique features, such as resistance to the neurotrophic factors, NGF, BDNF or bFGF (Figure 9A). In the present study, such cell death was found to be necrotic, without any apoptotic features (Figures 2-4). Compared to cells cultured in the presence of serum, $\left[{ }^{3} \mathrm{H}\right]-2-D G$ uptake into cells cultured in the absence of serum was markedly reduced (Figure 6a). This might be related to the rapid decrease in cellular ATP levels (Figure 1B), and to the induction of necrosis in serum-free culture (Figures 2-4). Our initial intention was to protect against necrotic death, following an addition of excess amount of glucose by raising cellular ATP 

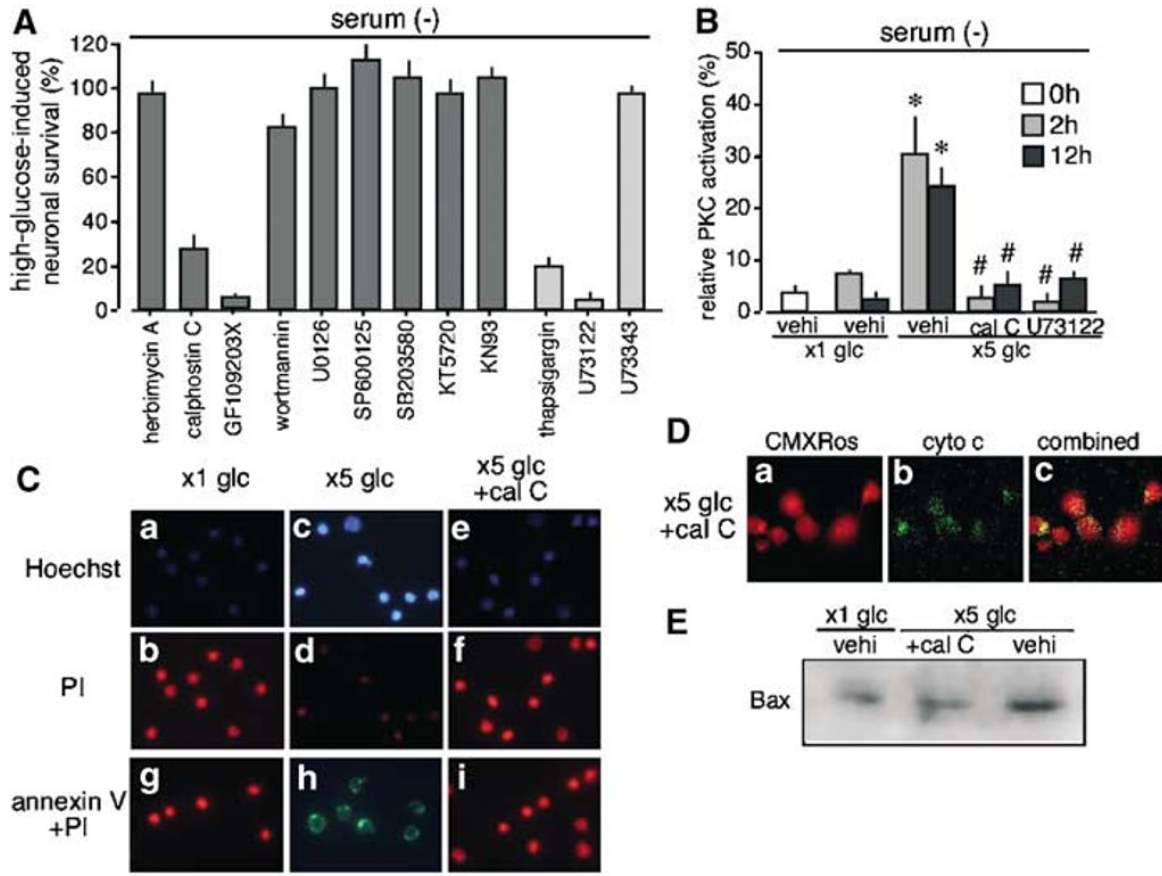

E

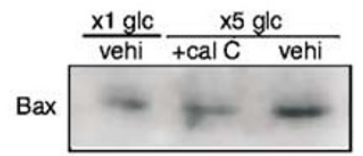

Figure 8 High-glucose-induced survival activity and cell death mode switch through protein kinase $\mathrm{C}$ activation. (A) Effects of various protein kinase inhibitors and reagents affecting $\mathrm{Ca}^{2}+$ dynamics. Cortical cells were seeded at $1 \times 10^{5} \mathrm{cells} / \mathrm{cm}^{2}$ with high glucose $(87.5 \mathrm{mM})$. Drugs were added to the culture at the beginning of the culture. Results represent the high-glucose-induced WST-8 reduction activity, which was subtracted by the activity in the normal glucose. However, all inhibitors used here alone had no significant effects on the WST-8 activity. Survival activity was measured by WST-8 $12 \mathrm{~h}$ after the start of culture. Neuronal survival was expressed as $\%$ inhibition of specific $\times 1$ glucose $(17.5 \mathrm{mM})$ cultures. Data show means \pm S.E.M. from three independent experiments. (B) Relative PKC activation was performed as described in Materials and Methods. Results are expressed as the means + S.E.M. from three independent experiments. (C) Double staining with Hoechst 33342 (a, $c$ and e)-PI (b, d and f) at $12 \mathrm{~h}$ and annexin V-PI (g-i) $3 \mathrm{~h}$ after the start of serum-free and $\times 1$ glucose $(\mathrm{a}, \mathrm{b}$ and g), $\times 5$ glucose $(\mathrm{c}, \mathrm{d}$ and $\mathrm{h})$ and $\times 5 \mathrm{glucose}+\mathrm{calphostin}$ $\mathrm{C}(3 \mu \mathrm{M})\left(\mathrm{e}, \mathrm{f}\right.$ and i) culture, respectively. (D) CMXRos (red; $\Delta \Psi_{\mathrm{m}}$ ) and cytochrome $c$ (FITC labeling: green; cyto $c$ ) staining were observed in cortical neurons treated with $\times 5$ glucose + calphostin $\mathrm{C}(3 \mu \mathrm{M})$ in the serum-free culture. (E) Immunoblot analyses of Bax expression in $\times 5$ glucose + calphostin $\mathrm{C}(3 \mu \mathrm{M})$ after incubation for $12 \mathrm{~h}$

levels. As expected, elevated glucose uptake inhibited necrosis in serum-free cultured neurons (Figure 2-4, 8C), which was correlated to slowing down of the decrease in cellular ATP levels (Figures 1B).

The cell death mode switch from necrosis to apoptosis by high-glucose treatment was clearly evidenced by SEM, TEM and immunocytochemical experiments using several specific molecular markers (Figures 2-4). Although the molecular mechanisms of necrosis induction and its inhibition by highglucose treatment in the serum-free culture remain to be determined, the decrease in cellular ATP levels is supposed to be involved in the necrosis-related osmotic imbalance, possibly through decreased $\mathrm{Na}^{+}-\mathrm{K}^{+}$ATPase activity and aquaporin membrane translocation. ${ }^{32-35}$ In the serum-free culture, there was a rapid decrease in $\left[{ }^{3} \mathrm{H}\right]-2-D G$ uptake activity, possibly due to loss of membrane translocation of GLUT 1 and GLUT4 (Figure 6b). High-glucose treatments showed moderate recovery of $\left[{ }^{3} \mathrm{H}\right]-2-D G$ uptake without changes in the membrane translocation of GLUT molecules (Figure 6a,b). Thus, the slowing of the decrease in cellular ATP levels and prevention of necrosis by high-glucose treatment are likely due to the moderate glucose incorporation through mechanisms distinct from GLUT1 or GLUT4. More direct evidence for the involvement of ATP rescue in the necrosis prevention was observed when pyruvate was added to the serum-free culture. Pyruvate showed more potent activity in raising survival activity and cellular ATP levels than high glucose (Figure 7a-c). Big difference between the effects of glucose and pyruvate would be seen in the fact that glucose treatment induced apoptosis as well as necrosis inhibition, while pyruvate did not induce apoptosis. Thus, it is suggested that high glucose has additional mechanisms to induce apoptosis.

Some molecular machineries related to high-glucoseinduced apoptosis were identified. Among several pathways to caspase- 3 activation, the cytochrome $c$ release regulated by Bcl-2 family proteins would be the major pathway. Although the serum-free stress itself had no effect on the proapoptotic cytochrome $c$ release, high-glucose treatments caused the release (Figure $5 \mathrm{C}$ ). High-glucose treatments increased the protein expression of Bax and Bim, both of which stimulate the release of cytochrome $c,{ }^{36,37}$ while decreased the expression of $\mathrm{Bcl}-\mathrm{xL}$, which inhibits the release (Figures $5 \mathrm{~A}, \mathrm{~B}){ }^{38,39} \mathrm{As}$ high-glucose stimulation caused a marked activation of caspase- 9 and caspase-3, the high-glucose-induced alteration of the expression of proapoptotic Bcl-2 family proteins may underlie cytochrome $c$ release and its downstream sequel to induce apoptosis.

From the study using enzyme inhibitors, it was found that the high-glucose-induced survival mechanisms are mediated through phospholipase C and PKC mechanisms. The PKC mechanisms were supposed to be also involved in the highglucose-induced cell death mode switch, as measured with Hoechst 33342-, PI-, annexin V-staining as well as 
A
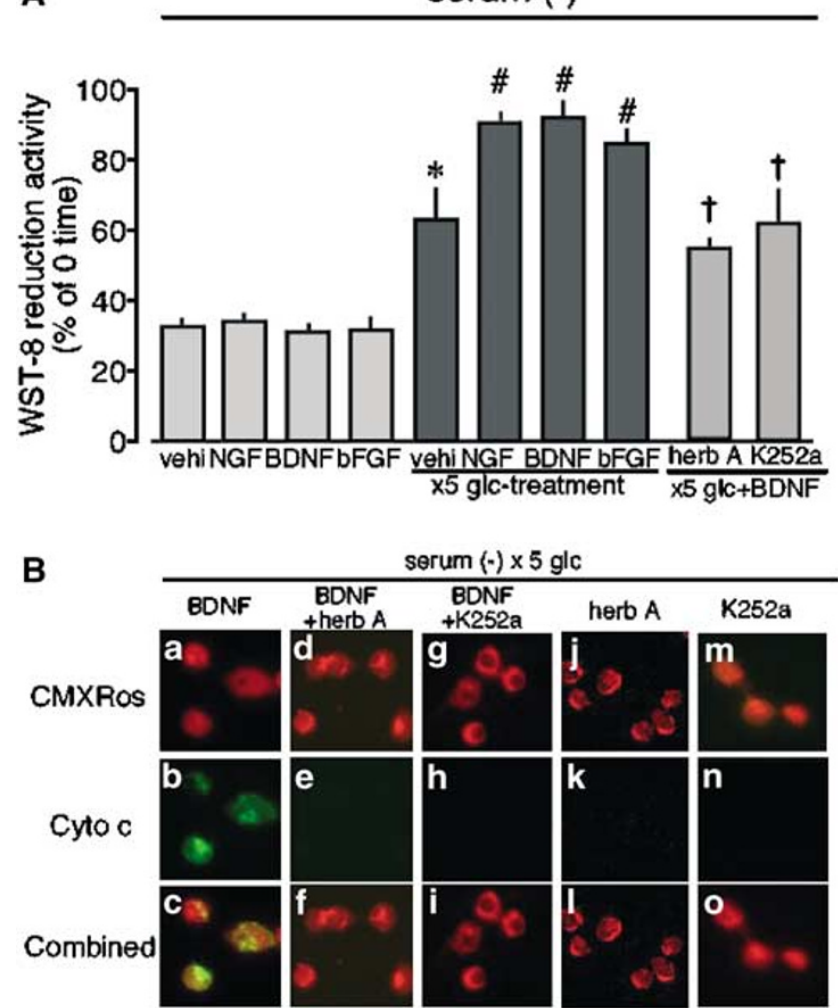

Figure 9 Potentiation of high-glucose-induced survival activity and blockade of high-cytochrome $c$ release by neurotrophic factors. (A) Potentiation of highglucose $(\times 5 \mathrm{glc})$-induced survival activity by several neurotrophic factors $(100 \mathrm{ng} / \mathrm{ml})$ in WST-8 reduction activity. Herbimycin A $(3 \mu \mathrm{M})$ and K252a $(1 \mu \mathrm{M}$, a TrkB receptor inhibitor) were added with high glucose and BDNF in beginning of serum-free culture in cortical neurons, $12 \mathrm{~h}$ after start of culture. The neurotrophic factors, NGF, BDNF and bFGF, were used at $100 \mathrm{ng} / \mathrm{ml}$. (B) CMXRos (red; $\Delta \Psi_{m}$ ) and cytochrome $c$ (FITC labeling: green; cyto $c$ ) staining were observed in cortical neurons treated with serum-free $5 \times$ glucose $+\operatorname{BDNF}(a-c)$, serum-free $\times 5$ glucose + BDNF + herbimycin A $(d-f)$, serum-free $\times 5$ gluco$\mathrm{se}+\mathrm{BDNF}+\mathrm{K} 252 \mathrm{a}(\mathrm{g}-\mathrm{i})$, serum-free $\times 5$ glucose + herbimycin $\mathrm{A}(\mathrm{j}-\mathrm{l})$, serum-free $\times 5$ glucose + K252a $(m-0)$, CMXRos $(a, d, g$, jand $m$ ), cytochrome $c(b, e, h, k$ and $n)$ and combined $(c, f, i, I$ and $o)$, respectively. Data $(\mathbf{A})$ are the means + S.E.M. from three independent experiments. ${ }^{*} P<0.05$, compared to $1 \times$ glucose vehicle, ${ }^{\sharp} P<0.05$, compared to $\times 5$ glucose vehicle, ${ }^{\dagger} P<0.05$, compared to $\times 5$ glucose + BDNF

cytochrome $c$ release and Bax protein expression (Figure $8 \mathrm{C}-\mathrm{E})$. As moderate incorporation of glucose by high-glucose treatment (Figure 6a) unlikely causes these apoptotic mechanisms, another mechanism should be considered. Most recently, it was reported that the G-protein-coupled receptor Gpr1p is involved in the high-glucose $(50 \mathrm{mM})$ induced $\left[\mathrm{Ca}^{2+}\right]_{i}$-increase, through an activation of phospholipase $C$ in budding yeast. ${ }^{40-42}$ Although any mammalian homologs are not found by database search at present, it might be a fascinating subject to relate the high-glucoseinduced cell death mode switch through PKC mechanisms to unidentified low-affinity glucose receptor.

In our previous study, the conditioned medium (CM) factors from high-density and serum-free culture also caused similar cell death mode switch through PKC mechanisms. ${ }^{17}$ Although $\mathrm{CM}$ factors do not appear to contain high amounts of glucose, the possibility that high glucose stimulates putative receptors for CM factors could not be excluded. However, the highglucose-induced PKC activation $(\sim 30 \%)$ was three times more potent than the $\mathrm{CM}$ factors $(\sim 10 \%)$, though the potencies in survival or apoptosis induction were equivalent between both factors. ${ }^{17}$ Thus, their receptor mechanisms stimulating PKC are likely different.

It is interesting to discuss the in vivo role of the present highglucose-induced cell death mode switch. The first issue is on the relationship between the concentration used for in vitro high-glucose treatment and in vivo glucose level in the ischemic brain. As seen in Figures 1,4 and 6, several changes related to this mode switch also occur when $\times 3$ glucose is used in vitro. On the other hand, there are reports that the local infarction of brain capillary vessels increased over two-fold blood and glucose supply in the penumbra. ${ }^{9,43}$ As it is reasonably expected that the higher increase in in vivo glucose level might occur in the specific area and/or during specific period after the ischemia, the high-glucose-induced neuronal death mode switch might have some roles in vivo.

The second issue is how the glucose application in vivo affects the ischemic neuronal damages. We observed that the topical vitreous application of glucose markedly prevented the neuronal necrosis in the retinal ischemia/reperfusion model, in which study coinjection of herbimycin A blocked the glucoseinduced neuroprotection, and caused apoptosis characterized by nuclear fragmentation in TEM analysis. These findings suggest that some neurotrophic factors secreted from unidentified cells may inhibit the glucose-induced apoptosis in vivo. ${ }^{44}$ This hypothesis may be in part confirmed by the present in vitro study. As shown in Figure 9, high-glucoseinduced survival activity was potentiated, while cytochrome $c$ release was blocked by BDNF and some other neurotropic factors, and these actions were completely abolished by tyrosine kinases. All these findings suggest that high-glucose treatments cause a cell death mode switch from necrosis to apoptosis, which in turn is liable to protection by serum factors or neurotrophic factors.

In conclusion, we demonstrated that the high-glucose treatments inhibit necrosis, possibly through slowing down the rapid decrease in cellular ATP levels, and at the same time induce apoptosis through phospholipase $\mathrm{C}$ and PKC mechanisms. The cell death mode switch mechanisms induced by high-glucose treatments may provide a new strategy of use of neurotrophic factors to cure necrosis in vivo.

\section{Materials and Methods}

\section{Materials}

Cell culture medium, fetal bovine serum (FBS) and herbimycin A were purchased from Gibco BRL (Tokyo, Japan). [ $\left.{ }^{32} \mathrm{P}\right]-$ ATP $(3000 \mathrm{Ci} / \mathrm{mmol})$ was bought from Amersham Pharmacia Biotech (Tokyo, Japan). $\left[{ }^{3} \mathrm{H}\right]$ deoxy-glucose $(10 \mathrm{Ci} / \mathrm{mmol})$ was from Daiichi Pure Chemicals (Tokyo Japan). D- $(+)$-glucose, D- $(+)$-mannose and SB203580 were bought from Nacalai Tesque (Kyoto Japan). Antibody against glucose transporter 1 (GULT1) and glucose transporter 4 (GLUT 4) were purchased from Santa Cruz Biotechnology (Santa Cruz, CA, USA). Pyruvate, U0126, KN93, K252a and thapsigargin were purchased from Sigma (Tokyo, Japan). Calphostin $C$ and wortmannin were purchased from Wako Pure Chemicals (Tokyo, Japan). KT5720, U73122 and U73343 were purchased 
from Funakoshi (Tokyo, Japan). GF109203X was purchased from Calbiochem (San Diego, CA, USA). Herbimycin A was purchased from LKT laboratories (St. Paul, MN, USA). Neuronal growth factor (NGF) was purchased from Alomone Labs. (Jerusalem, Israel). bFGF was purchased from Austral Biologicals (San Ramon, CA, USA). BDNF was a gift from Sumitomo Pharmaceutical (Osaka, Japan). SP600125 was a gift from T Iwamura (Gifu Pharmaceutical University).

\section{Primary culture}

Primary cultures of 17-day embryonic rat cerebral cortex cells were produced according to the previously reported protocol. ${ }^{17,45}$ Different groups of cultures were supplemented with $0,17.5,35.0,52.5$ and $70 \mathrm{mM}$ glucose (final glucose concentration, 17.5, 35.0, 52.5, 70.0 and $87.5 \mathrm{mM}$ ). They were seeded onto 96-well culture plates, eight-well Lab-Tek ${ }^{\mathrm{TM}}$ chambers, or 3.5 and $9.0 \mathrm{~cm}$ culture dishes, which had been all coated with poly-DL-ornithine, and cultured at $37^{\circ} \mathrm{C}$ in $5 \%-\mathrm{CO}_{2}$ atmosphere.

\section{Measurement of intracellular ATP levels}

Intracellular ATP levels were measured by the luciferin-luciferase method, using ATP-Determination Kit (Molecular Probes, Eugene, OR, USA). ${ }^{46}$ The entire cells of culture including any floating cells $\left(2 \times 10^{6}\right.$ cells) were subjected to the assay. The cells were twice washed with ice-cold phosphate-buffered saline (PBS) and suspended in cell dilution buffer ( $4 \mathrm{mM}$ EDTA, $100 \mathrm{mM}$ Tris- $\mathrm{HCl}$ pH7.75). Aliquots $(20 \mu \mathrm{l})$ of cell lysates were added with the Reaction Solution (200 $\mu \mathrm{l})$ containing $0.5 \mu \mathrm{M}$ luciferin, $1.25 \mu \mathrm{g} / \mathrm{ml}$ luciferase and $1 \mu \mathrm{M}$ DL-dithiothreitol (DTT) from the Kit, and used for bioluminescence assay, using LUMAT LB 9507 from EG\&G Berthold (Bad Wildbad, Germany).

\section{WST-8 assay}

To assess the viability of cells, we performed 2-(2-methoxy-4-nitrophenyl)3-(4-nitrophenyl)-5-(2,4-disulfophenyl)-2H-tetrazolium, monosodium salt (WST-8) reduction assay kit (Dojin Lab., Tokyo, Japan), according to the manufacturer's instructions. WST-8 was added to the culture for $3 \mathrm{~h}$ at $37^{\circ} \mathrm{C}$ prior to the colorimetry. Percentage of WST-8 activity was represented as the ratio of activity at different time points to that in the beginning of culture.

\section{LDH release assay}

Cell damage was quantified by measuring activities of the cytosolic lactate dehydrogenase $(\mathrm{LDH})$ released into the culture medium from damaged cells, by using the Cytotoxicity Detection Kit from Roche Molecular Biochemicals (Mannheim, Germany) according to the manufacturer's instructions. Briefly, cells $\left(3.2 \times 10^{3}\right.$ cells $/ 100 \mu /$ well $)$ were seeded on a 96-well culture dish. For maximum LDH release, $100 \mu$ of $2 \%$ Triton X-100 was added to the culture $(100 \mu \mathrm{l})$, and incubated for $30 \mathrm{~min}$ at $25^{\circ} \mathrm{C}$. Aliquots $(100 \mu l)$ of lysates were transferred to a 96 -well dish, and then the reaction mixture $(100 \mu l)$ from the Kit was added to the wells and incubated for $90 \mathrm{~min}$ at $25^{\circ} \mathrm{C}$ in the dark. Enzyme activity was evaluated by colorimetry. For the LDH release into the culture medium from cells at corresponding periods, aliquots $(50 \mu \mathrm{l})$ of culture medium were transferred to a 96-well dish and added with $50 \mu \mathrm{l}$ of $2 \%$ Triton X-100, followed by the procedures, as mentioned above. Results were represented as the percentage of the maximum LDH release.

\section{Scanning electron microscopy}

Cultured cortical neuron was seeded in the cover glass for SEM. Neurons were rinsed briefly in PBS (pH 7.4), and fixed in $2.5 \%$ glutaraldehyde in $0.1 \mathrm{M} \mathrm{PBS}(\mathrm{pH} 7.4)$ overnight at $4^{\circ} \mathrm{C}$. Neurons were then rinsed in buffer, and postfixed with $2 \%$ osmium tetroxide for $1 \mathrm{~h}$ at $25^{\circ} \mathrm{C}$. Dehydration was carried out through an ascending series of alcohols, transferred to isoamyl acetate and a critical-point -drier was used. Finally, these samples were sputter coated with gold/palladium. The stained samples were observed under an electron microscope (JSM-35C; JEOL, Tokyo, Japan).

\section{Transmission electron microscopy}

Cultured cortical neurons were fixed with $2.5 \%$ glutaraldehyde in $0.1 \mathrm{M}$ phosphate buffer $(\mathrm{pH} 7.4)$ for $1 \mathrm{~h}$ at $25^{\circ} \mathrm{C}$. The fixed cortical neurons were postfixed with $2 \%$ osmium tetroxide for $1 \mathrm{~h}$ at $25^{\circ} \mathrm{C}$, dehydrated in graded alcohol series, and embedded in Epon812. Ultrathin sections ( $80 \mathrm{~nm}$ thick) were cut with an Ultracut $S$ (Leica, Austria), and then stained with uranyl acetate and lead citrate for 30 and $5 \mathrm{~min}$, respectively. The stained sections were observed under an electron microscope (JEM-1210; JEOL, Tokyo, Japan).

\section{Annexin V-binding and PI-staining assay}

To assess the simultaneous observation of early phase of apoptotic and necrotic features, cortical cells on an eight-well Lab-Tek ${ }^{\mathrm{TM}}$ chamber were treated with annexin V-fluorescein (annexin V-FLUOS Staining Kit from Roche Molecular Biochemicals) and $10 \mu \mathrm{g} / \mathrm{ml} \mathrm{PI}$ for $15 \mathrm{~min}$ at $25^{\circ} \mathrm{C}$ in the dark. Cells were washed once with ice-cold PBS, fixed with $4 \%$ paraformaldehyde (PFA) in PBS for $30 \mathrm{~min}$ at $25^{\circ} \mathrm{C}$, and observed under a fluorescence microscope (LSM 410; Carl Zeiss; Tokyo, Japan).

\section{Immunocytochemistry of caspase-3}

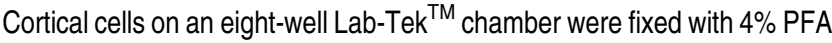
in PBS for $30 \mathrm{~min}$, followed by permeabilization using $0.1 \%$ Triton X-100 in PBS. They were incubated in blocking buffer ( $2 \%$ low-fat milk powder, $2 \%$ bovine serum albumin, $0.1 \%$ Tween-20, in PBS, pH 7.4) for $1 \mathrm{~h}$ at $25^{\circ} \mathrm{C}$. Anticleaved caspase-3 antibody ( $1: 50$; Cell Signaling, Tokyo, Japan) was added to the cells. After $2 \mathrm{~h}$ incubation at $25^{\circ} \mathrm{C}$ and washing, the cells were incubated with FITC-conjugated anti-rabbit immunoglobulin $(\mathrm{lgG})(1: 200$; Cappel, Aurora) for $4 \mathrm{~h}$ at $25^{\circ} \mathrm{C}$. Immunolabeled cells were observed under a fluorescence microscope.

\section{TUNEL analysis}

DNA fragmentation in apoptotic cells was visualized by terminal deoxyribonucleotidyl transferase-mediated dUTP-biotin nick endlabeling (TUNEL, Invitrogen, Tokyo, Japan). ${ }^{47}$ Cells on an eight-well Lab-Tek ${ }^{\mathrm{TM}}$ chamber, preincubated with $10 \mu \mathrm{g} / \mathrm{ml} \mathrm{PI}$ at $37^{\circ} \mathrm{C}$ for $30 \mathrm{~min}$, were washed twice in ice-cold PBS, fixed with $4 \%$ PFA in PBS for $30 \mathrm{~min}$, and permeabilized with 50 and $100 \%$ methanol for $5 \mathrm{~min}$ each. The treated cells were reacted with the TUNEL solution from Roche Molecular Biochemicals for $1 \mathrm{~h}$ at $37^{\circ} \mathrm{C}$. They were washed twice in PBS, and added by blocking buffer ( $1 \%$ bovine serum albumin in PBS, pH 7.4) for $1 \mathrm{~h}$ at $25^{\circ} \mathrm{C}$, followed by incubation with streptavidin-FITC (1:100; Vector Laboratories, Burlingame, CA, USA) for $1.5 \mathrm{~h}$ at $25^{\circ} \mathrm{C}$, for observation with fluorescence microscope. 


\section{Measurement of activity of caspase-3-like proteases}

Culture cells were lysed with lysis buffer $(0.5 \%$ Triton X-100, $20 \mathrm{mM}$ EDTA and $50 \mathrm{mM}$ Tris- $\mathrm{HCl}, \mathrm{pH}$ 8.1). The cell lysate was centrifuged at $15000 \mathrm{rpm}$ for $10 \mathrm{~min}$, and the supernatant was used for the enzymatic assay. The diluted cell lysate $(12 \mu \mathrm{l} ; 1-3 \mathrm{mg} / \mathrm{ml})$ was added to $380 \mu \mathrm{l}$ of reaction buffer $(0.1 \%$ Triton X-100, $20 \%$ glycerol, $0.5 \mathrm{mM}$ EDTA, $1 \mathrm{mM}$ fluorogenic peptide substrate, acetyl-Asp-GluVal-Asp-a-(4-methyl-coumaryl-7-amide) (Ac-DEVD-MCA) for caspase-3like protease activity, and was incubated for $1 \mathrm{~h}$ at $30^{\circ} \mathrm{C}$. The reaction was terminated by addition of $350 \mu \mathrm{l}$ of $0.2 \mathrm{M}$ glycine- $\mathrm{HCl}, \mathrm{pH} 2.8$. Enzyme-catalyzed release of 7-amino-4-methyl-coumarine (MAC) was measured by a fluorospectrometer (excitation $380 \mathrm{~nm}$, emission $460 \mathrm{~nm}$ ). Caspase-3-like protease activities in the extracts were represented as the value of increase in aminomethylcoumarin (AMC) fluorescence per hour per microgram of protein. One unit of enzyme is defined as the amount of enzyme required to release $0.03 \mu \mathrm{M}$ of $\mathrm{AMC}$ per $\mathrm{min}$ at $30 \mathrm{~min}$.

\section{Analysis of DNA fragmentation}

Cells $\left(1 \times 10^{5} \mathrm{cells} / \mathrm{cm}^{2}\right)$ on $9-\mathrm{cm}$ dishes were harvested and centrifuged at $350 \times g$ for $5 \mathrm{~min}$, and the pellet was used for DNA fragmentation analysis, as previously described. ${ }^{48}$ Briefly, the cells were lysed in $250 \mu$ l of lysis buffer $(5 \mathrm{mM}$ Tris- $\mathrm{HCl}, 20 \mathrm{mM}$ EDTA and $0.5 \%$ Triton $\mathrm{X}-100, \mathrm{pH} 8.1$ ) with gentle shaking for $15 \mathrm{~min}$ at $4^{\circ} \mathrm{C}$. The lysates were centrifuged at $6000 \times g$ for $10 \mathrm{~min}$ at $4^{\circ} \mathrm{C}$ to separate the fragmented DNA (supernatant) and intact chromatin DNA (pellet). The fragmented DNA was extracted with phenol/chloroform/isoamylalcohol, and the DNA in the aqueous phase was precipitated with 2 volumes of ethanol following the addition of sodium acetate (final concentration, $0.3 \mathrm{M})$. The DNA was then collected by centrifugation $(14000 \times g$ for $10 \mathrm{~min}$ at $4^{\circ} \mathrm{C}$ ) and dried. The samples were finally dissolved in TE buffer (10 mM Tris- $\mathrm{HCl}$ and $1 \mathrm{mM}$ EDTA, pH 8.1), incubated for $1 \mathrm{~h}$ at $37^{\circ} \mathrm{C}$ with RNase A $(10 \mu \mathrm{g} / \mathrm{ml})$, and electrophoresed on a $2 \%$ agarose gel. The gel was stained with ethidium bromide, and then photographed on an ultraviolet illuminator.

\section{Western blot analysis}

SDS-polyacrylamide gel electrophoresis by using $12 \%$ polyacrylamide gel and immunoblot analysis was performed as described. ${ }^{49}$ Anti-Bcl-2, antiBax, anti-Bim, anti-Bcl-xL (1:1000; Santa Cruz Biotechnology, CA), anticleaved caspase-3 (1:1000; Cell Signaling, Tokyo, Japan), anticaspase-8, anticaspase-9 (1:1000; Stressgen, Victoria, Canada) and anticaspase-12 (1:1000; Oncogene, CA, USA) were used as primary antibodies. Visualization of immunoreactive bands was performed by using an enhanced chemiluminescent substrate (Super Signaling Substrate; Pierce Chemical Co., Rockford, IL, USA) for the detection of horseradish peroxidase.

\section{Mitotracker red CMXRos and cytochrome $c$ double labeling}

Cortical cells on an eight-well Lab-Tek ${ }^{\mathrm{TM}}$ chamber were incubated with $100 \mathrm{nM}$ Mitotracker Red CMXRos (Molecular Probes, Eugene, OR, USA) for $30 \mathrm{~min}$ at $37^{\circ} \mathrm{C}$ in the culture medium. After incubation with CMXRos, the cells were washed with ice-cold PBS, and then fixed with $4 \%$ PFA in PBS for $30 \mathrm{~min}$ at $25^{\circ} \mathrm{C}$. Cells were permeabilized with $0.1 \%$ Triton $\mathrm{X}-100$ for $5 \mathrm{~min}$ at $4^{\circ} \mathrm{C}$, and washed twice with ice-cold PBS, then incubated in blocking buffer $(2 \%$ bovine serum albumin, $0.1 \%$ Tween-20, in PBS, pH 7.4) for $1 \mathrm{~h}$ at $25^{\circ} \mathrm{C}$. The primary antibody (anticytochrome $c$, clone 6H2.B4; 1:100; PharMingen, San Diego, CA, USA) that recognizes the native form of cytochrome $c$ was then added to the cells at a concentration of $10 \mu \mathrm{g} / \mathrm{ml}$ for $4 \mathrm{~h}$ at $25^{\circ} \mathrm{C}$. After washing ice-cold PBS, biotin-conjugated anti-mouse IgG (1: 1000; Vector Laboratories, Burlingame, CA, USA) was added for $2 \mathrm{~h}$ at $25^{\circ} \mathrm{C}$. After washing ice-cold PBS, the cells were then added streptavidin-FITC conjugates for $1 \mathrm{~h}$ at $25^{\circ} \mathrm{C}(1: 100$; Venn Nova LLC, FL, USA). CMXRos and FITC fluorescence were observed under a fluorescence microscope.

\section{2-Deoxy-D- $\left[{ }^{3} \mathrm{H}\right]$ glucose uptake}

2-Deoxy-D-[ $\left.{ }^{3} \mathrm{H}\right]$ glucose $\left(\left[{ }^{3} \mathrm{H}\right]-2-\mathrm{DG}\right.$; NEN, Boston, MA, USA) uptake was measured using modified Koivisto's methods. ${ }^{50}$ Briefly, $\left[{ }^{3} \mathrm{H}\right]-2-\mathrm{DG}$ $(1 \mu \mathrm{Ci} /$ well, $10 \mathrm{nM})$ was added to the six-well culture dishes in the beginning of culture and incubated for $2 \mathrm{~h}$ at $37^{\circ} \mathrm{C}$ in $5 \%-\mathrm{CO}_{2}$ atmosphere. Uptake of $\left[{ }^{3} \mathrm{H}\right]-2-D G$ was terminated by a rapid removal of the medium, followed by washes twice with ice-cold PBS (pH 7.4). The cells were lysed in $100 \mu \mathrm{l}$ of $0.5 \mathrm{M} \mathrm{NaOH}$, followed by neutralization with $0.5 \mathrm{M}$ $\mathrm{HCl}$. The radioactivity of collected cell lysates was determined by a liquid-scintillation counter. Cellular glucose incorporation was evaluated by the $\left[{ }^{3} \mathrm{H}\right]-2-D G$ uptake for $2 \mathrm{~h}$ from the start of $1 \times$ glucose $(17.5 \mathrm{mM})$ containing serum-plus culture, or $1 \times, 3 \times$ and $5 \times$ glucose $(17.5,52.5$ and $87.5 \mathrm{mM})$ containing serum-free culture. Results represent pmol glucose equivalent per $2 \mathrm{~h}$, regarding a tracer $\left[{ }^{3} \mathrm{H}\right]-2-\mathrm{DG}$ as glucose.

\section{PKC kinase assay}

Cultured cells were harvested using a solution containing $0.3 \%$ $\beta$-mercaptoethanol, $5 \mathrm{mM}$ EDTA, $10 \mathrm{mM}$ EGTA, $50 \mu \mathrm{g} / \mathrm{ml} \mathrm{PMSF}, 10 \mathrm{mM}$ benzamidine and $50 \mathrm{mM}$ Tris- $\mathrm{HCl}(\mathrm{pH} 7.5)$, homogenized on ice, and added to an equal volume of glycerol. PKC assay was performed using the Protein Kinase $C$ enzyme assay system (Amersham Pharmacia Biotech, Piscataway, NJ, USA), according to the manufacturer's instructions with modifications. Briefly, the samples [S] were incubated with the substrate peptide, to be phosphorylated by PKC in $50 \mathrm{mM}$ Tris$\mathrm{HCl}(\mathrm{pH} 7.5), 30 \mathrm{mM}$ dithiothreitol and $\left[\gamma^{32} \mathrm{P}\right] \mathrm{ATP}$ in magnesium ATP buffer (1.2 mM ATP, $30 \mathrm{mM} \mathrm{HEPES}$ and $72 \mathrm{mM} \mathrm{MgCl}_{2}, \mathrm{pH} 7.4$ ) for $15 \mathrm{~min}$ at $37^{\circ} \mathrm{C}$. Maximum PKC activation (Max) was obtained by further addition of $0.3 \mathrm{mg} / \mathrm{ml} \mathrm{L} \alpha$-phosphatidyl-L-serine, $24 \mu \mathrm{g} / \mathrm{ml}$ phorbol 12-myristate 13acetate and $12 \mathrm{mM}$ calcium acetate in $50 \mathrm{mM}$ Tris- $\mathrm{HCl}$ (pH 7.5). Background activation [B] was obtained by omitting substrate peptide from [S] reaction mixture. After addition of stop solution, the reaction mixture was transferred onto peptide-binding paper. These papers were washed twice with $5 \%$ acetic acid and the incorporation of ${ }^{32} \mathrm{P}$ into peptide was determined by a liquid scintillation counter. PKC activation was calculated by the equation PKC activation $(\%)=([\mathrm{S}]-[\mathrm{B}]) /$ $([\mathrm{Max}]-[\mathrm{B}]) \times 100$.

\section{Statistical analysis}

For the statistical analysis of data, Student's $t$-test following multiple comparisons of the analysis of variance (ANOVA) was used. The criterion of significance was set at * or $P<0.05$. All results are expressed as the mean + S.E.M. 


\section{Acknowledgements}

We gratefully acknowledge M Niwa and T Suematsu for helps in SEM and TEM studies, T Iwamura (Gifu Pharmaceutical University) for SP600125, JNK inhibitor, and A Yoshida, M Ueda, W Hamabe and M Rikumaru for technical help. We thank Sumitomo Pharmaceutical (Osaka, Japan) for the gift of BDNF. Parts of this study were supported by Grants-in-Aid and Special Coordination Funds from the Ministry of Education, Culture, Sports, Science and Technology.

\section{References}

1. Faden Al (1996) Pharmacological treatment of central nervous system trauma. Pharmacol. Toxicol. 78: 12-17

2. Rink A, Fung KM, Trojanowski JQ, Lee VM, Neugebauer E and McIntosh TK (1995) Evidence of apoptotic cell death after experimental traumatic brain injury in the rat. Am. J. Pathol. 147: 1575-1583

3. Yakovlev AG, Knoblach SM, Fan L, Fox GB, Goodnight R and Faden AI (1997) Activation of CPP32-like caspases contributes to neuronal apoptosis and neurological dysfunction after traumatic brain injury. J. Neurosci. 17: 74157424

4. Yuan XQ, Prough DS, Smith TL and Dewitt DS (1988) The effects of traumatic brain injury on regional cerebral blood flow in rats. J. Neurotrauma 5: 289-301

5. Yamakami I and McIntosh TK (1989) Effects of traumatic brain injury on regional cerebral blood flow in rats as measured with radiolabeled microspheres. J. Cereb. Blood Flow Metab. 9: 117-124

6. Bouma GJ, Muizelaar JP, Choi SC, Newlon PG and Young HF (1991) Cerebral circulation and metabolism after severe traumatic brain injury: the elusive role of ischemia. J. Neurosurg. 75: 685-693

7. Muizelaar JP and Schroder ML (1994) Overview of monitoring of cerebral blood flow and metabolism after severe head injury. Can. J. Neurol. Sci. 21: S6-S11

8. Furlan M, Marchal G, Viader F, Derlon JM and Baron JC (1996) Spontaneous neurological recovery after stroke and the fate of the ischemic penumbra. Ann. Neurol. 40: 216-226

9. Dirnagl U, ladecola C and Moskowitz MA (1999) Pathobiology of ischaemic stroke: an integrated view. Trends Neurosci. 22: 391-397

10. Becker KJ (1998) Inflammation and acute stroke. Curr. Opin. Neurol. 11: 45-49

11. MacManus JP and Linnik MD (1997) Gene expression induced by cerebral ischemia: an apoptotic perspective. J. Cereb. Blood Flow Metab. 17: 815-832

12. Osuga $H$, Osuga $S$, Wang $F$, Fetni R, Hogan MJ, Slack RS, Hakim AM, Ikeda JE and Park DS (2000) Cyclin-dependent kinases as a therapeutic target for stroke. Proc. Natl. Acad. Sci. U.S.A. 97: 10254-10259

13. Kerr JF, Wyllie AH and Currie AR (1972) Apoptosis: a basic biological phenomenon with wide-ranging implications in tissue kinetics. Br. J. Cancer 26: 239-257

14. Bredesen DE (1995) Neural apoptosis. Ann. Neurol. 38: 839-851

15. Yuan J and Yankner BA (2000) Apoptosis in the nervous system. Nature 407: 802-809

16. Fujita R, Yoshida A, Mizuno K and Ueda $\mathrm{H}$ (2001) Cell density-dependent death mode switch of cultured cortical neurons under serum-free starvation stress. Cell. Mol. Neurobiol. 21: 317-324

17. Fujita $R$ and Ueda $H$ (2003) Protein kinase C-mediated necrosis-apoptosis switch of cortical neurons by conditioned medium factors secreted under the serum-free stress. Cell Death Differ. 10: 782-790

18. Lee YJ and Shacter E (1999) Oxidative stress inhibits apoptosis in human lymphoma cells. J. Biol. Chem. 274: 19792-19798

19. Eguchi $Y$, Shimizu S and Tsujimoto $Y$ (1997) Intracellular ATP levels determine cell death fate by apoptosis or necrosis. Cancer Res. 57: 1835-1840

20. Leist M, Single B, Castoldi AF, Kuhnle S and Nicotera P (1997) Intracellular adenosine triphosphate (ATP) concentration: a switch in the decision between apoptosis and necrosis. J. Exp. Med. 185: 1481-1486

21. Richter C, Schweizer M, Cossarizza A and Franceschi C (1996) Control of apoptosis by the cellular ATP level. FEBS Lett. 378: 107-110

22. Tsujimoto $Y$ (1997) Apoptosis and necrosis: intracellular ATP levels as a determinant cell death mode. Cell Death Differ. 4: 429-434
23. Nicotera $P$ and Leist $M$ (1997) Energy supply and the shape of death in neurons and lymphoid cells. Cell Death Differ. 4: 435-442

24. Vermes I, Haanen C, Steffens-Nakken H and Reutelingsperger C (1995) A novel assay for apoptosis. Flow cytometric detection of phosphatidylserine expression on early apoptotic cells using fluorescein labelled Annexin V. J. Immunol. Methods 184: 39-51

25. Kouroku Y, Urase K, Fujita E, Isahara K, Ohsawa Y, Uchiyama Y, Momoi MY and Momoi T (1998) Detection of activated caspase-3 by a cleavage sitedirected antiserum during naturally occurring DRG neurons apoptosis. Biochem. Biophys. Res. Commun. 247: 780-784

26. Green DR and Reed JC (1998) Mitochondria and apoptosis. Science 281: 1309-1312

27. Shimizu S, Narita M and Tsujimoto Y (1999) Bcl-2 family proteins regulate the release of apoptogenic cytochrome $c$ by the mitochondrial channel VDAC. Nature 399: 483-487

28. Tsujimoto Y and Shimizu S (2000) Bcl-2 family: life-or-death switch. FEBS Lett. 466: 6-10

29. Kaufmann SH and Hengartner MO (2001) Programmed cell death: alive and well in the new millennium. Trends Cell Biol. 11: 526-534

30. Ashkenazi A and Dixit VM (1998) Death receptors: signaling and modulation. Science 281: 1305-1308

31. Nakagawa T, Zhu H, Morishima N, Li E, Xu J, Yankner BA and Yuan J (2000) Caspase-12 mediates endoplasmic-reticulum-specific apoptosis and cytotoxicity by amyloid-beta. Nature 403: 98-103

32. Lees GJ, Lehmann A, Sandberg M and Hamberger A (1990) The neurotoxicity of ouabain, a sodium-potassium ATPase inhibitor, in the rat hippocampus. Neurosci. Lett. 120: 159-162

33. Lees GJ and Leong W (1994) Brain lesions induced by specific and non-specific inhibitors of sodium-potassium ATPase. Brain Res. 649: $225-233$

34. Towne JE, Krane CM, Bachurski CJ and Menon AG (2001) Tumor necrosis factor-alpha inhibits aquaporin 5 expression in mouse lung epithelial cells. J. Biol. Chem. 276: 18657-18664

35. Senatorov VV, Stys PK and Hu B (2000) Regulation of $\mathrm{Na}^{+}, \mathrm{K}^{+}$-ATPase by persistent sodium accumulation in adult rat thalamic neurones. J. Physiol. 525, (Part 2) 343-353

36. Marzo I, Brenner C, Zamzami N, Jurgensmeier JM, Susin SA, Vieira HL, Prevost MC, Xie Z, Matsuyama S, Reed JC and Kroemer G (1998) Bax and adenine nucleotide translocator cooperate in the mitochondrial control of apoptosis. Science 281: 2027-2031

37. Putcha GV, Moulder KL, Golden JP, Bouillet P, Adams JA, Strasser A and Johnson EM (2001) Induction of BIM, a proapoptotic BH3-only BCL-2 family member, is critical for neuronal apoptosis. Neuron 29: 615-628

38. Yang J, Liu X, Bhalla K, Kim CN, Ibrado AM, Cai J, Peng TI, Jones DP and Wang X (1997) Prevention of apoptosis by Bcl-2: release of cytochrome $c$ from mitochondria blocked. Science 275: 1129-1132

39. Kluck RM, Bossy-Wetzel E, Green DR and Newmeyer DD (1997) The release of cytochrome $c$ from mitochondria: a primary site for $\mathrm{Bcl}-2$ regulation of apoptosis. Science 275: 1132-1136

40. Tisi R, Baldassa S, Belotti F and Martegani E (2002) Phospholipase $C$ is required for glucose-induced calcium influx in budding yeast. FEBS Lett. 520: $133-138$

41. Xue Y, Batlle M and Hirsch JP (1998) GPR1 encodes a putative $G$ protein-coupled receptor that associates with the Gpa2p Galpha subunit and functions in a Ras-independent pathway. EMBO J. 17: 1996-2007

42. Ansari K, Martin S, Farkasovsky M, Ehbrecht IM and Kuntzel H (1999) Phospholipase C binds to the receptor-like GPR1 protein and controls pseudohyphal differentiation in Saccharomyces cerevisiae. J. Biol. Chem. 274: 30052-30058

43. Hossmann KA (1994) Viability thresholds and the penumbra of focal ischemia. Ann. Neurol. 36: 557-565

44. Fujita R and Ueda $H$ (2002) Glucose-induced neuroprotection through necrosis-apoptosis switch under the serum-free condition. SFN 32nd Annual Meeting. Program No. 198: 15

45. Hamabe W, Fujita R, Yasusa T, Yoneda F, Yoshida A and Ueda H (2000) 1 (Benzofuran-2-yl)-2-propylaminopentane shows survival effect on cortical neurons under serum-free condition through sigma receptors. Cell. Mol. Neurobiol. 20: 695-702 
46. Ha HC and Snyder SH (1999) Poly(ADP-ribose) polymerase is a mediator of necrotic cell death by ATP depletion. Proc. Natl. Acad. Sci. U.S.A. 96: 13978-13982

47. Gavrieli Y, Sherman $Y$ and Ben-Sasson SA (1992) Identification of programmed cell death in situ via specific labeling of nuclear DNA fragmentation. J. Cell Biol. 119: 493-501

48. Yoshida A and Ueda H (1999) Activation of Gi1 by lysophosphatidic acid receptor without ligand in the baculovirus expression system. Biochem. Biophys. Res. Commun. 259: 78-84
49. Yoshida A, Tokuyama S, Iwamura T and Ueda H (2000) Opioid analgesicinduced apoptosis and caspase-independent cell death in human lung carcinoma A549 cells. Int. J. Mol. Med. 6: 329-335

50. Koivisto UM, Martinez-Valdez H, Bilan PJ, Burdett E, Ramlal T and Klip A (1991) Differential regulation of the GLUT-1 and GLUT-4 glucose transport systems by glucose and insulin in L6 muscle cells in culture. J. Biol. Chem. 266: 2615-2621 